\title{
A JUNE BIRD DRIVE
}

VICTOR C. FRIESEN, P.O. Box 65, Rosthem, SK SOK 3R0

My wife Dorothy and I enjoy bird "drives" as much as bird walks. The countryside east of our home in Rosthern has a rich variety of habitat for all kinds of birdlife (and splendid prospects for landscape photography). So we mosey along, stopping often to look and listen (and photograph). "What is so rare as a day in June?" poet James Russell Lowell has asked, and the late afternoon and evening of 3 June 1997 is indeed a special day in our travels. Here are some of our observations.

Our journey begins along Highway 312 and takes us first to Gabriel Bridge, where a trail leads down to the old ferry crossing. There, a Spotted Towhee, still common along river ravines in the northern part of its breeding range, hops in the dust. It darts among the nearby willows, and we hear its mewing call, a repetition of its name. After a while its not un-

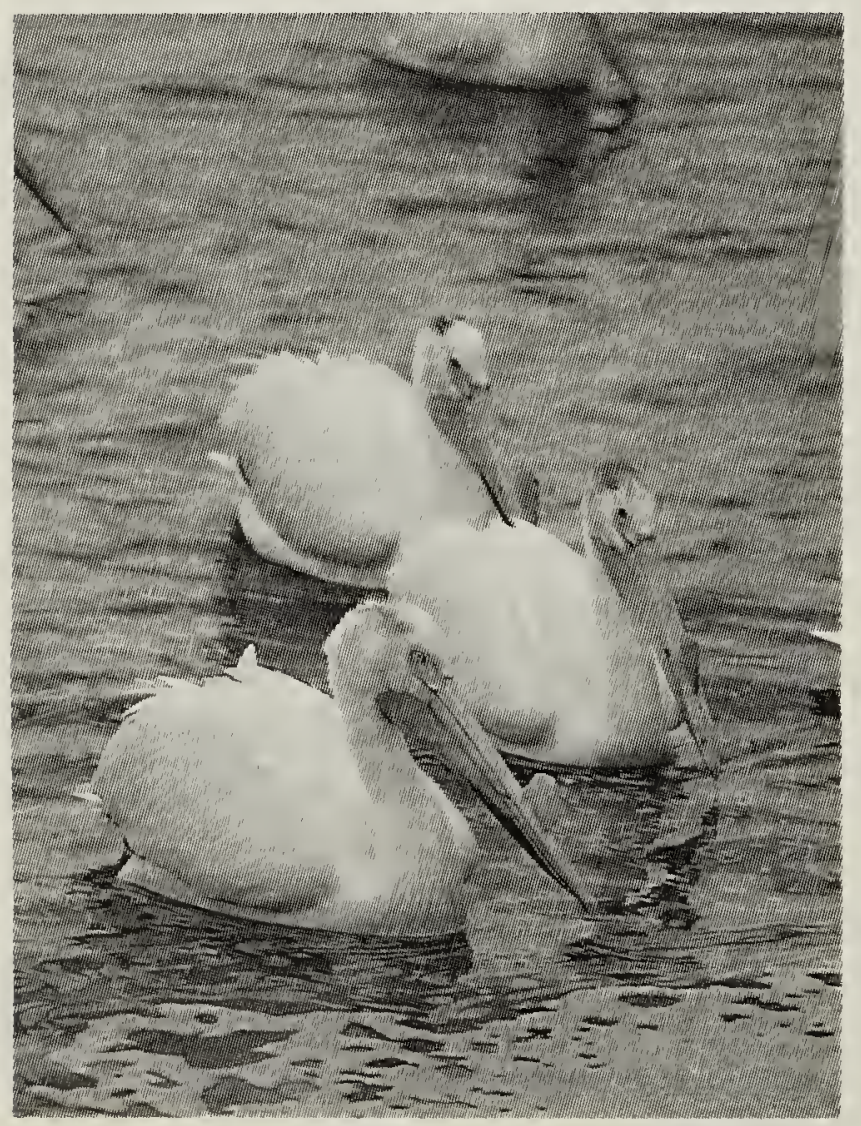

American White Pelicans

George Tosh musical song greets us repeatedly: chup, chup, chup, chup, zee-ee-ee$e e$. We are glad that we stopped, for in the background a White-throated Sparrow whistles its "five pure notes succeeding pensively," as another poet, Archibald Lampman, has said. It is just in the last few years that I have heard this sparrow's song this late in the season at Rosthern.

As we drive over the bridge, we notice the absence of Cliff Swallows, which once swooped and fluttered (and chattered) about the steel arches in dozens, if not hundreds, for they nested under the roadway. In 1995, the bridge was sandblasted and repainted, but I suspect that in a year or two the swallows will be back. (Once a robin's-egg blue, the bridge is now a teal green.) Of note are the American White Pelicans, one flying beneath the bridge as we cross, three more on the shoreline, and yet another sunning itself on a rock in midstream.

Two-thirds of the way to Wakaw, our turn-around point 25 miles distant, we drive among a series of alkali flats, now water-covered and ringed with crusty shorelines (on one occasion I was able to photograph striking concentric circles of blue water, white shore, red samphire, and bordering tawny grass). Pas these flats and slipping through $a$ valley in the Minichinas Hills, we spy a Great Blue Heron flapping along neck a-crook, and, as Henry Davic Thoreau has written, "carry[ing] its precious legs away to deposit then in a place of safety." We may mee the bird again. 
Nearing another alkaline water more of a slough this time (the salty smell is invigorating) - I spot what I think is a Western Meadowlark on a nearby fence post, but on driving by, I identify the bird as a Common Snipe. I back up slowly for a better view. The bird stolidly maintains its position, the jagged lines of black and buff feather tips on its upper body showing to advantage in the bright sunlight. I am familiar with this species from earlier in spring when it zigzags above the town's reservoir, making its winnowing courtship flight/sound.

The journey resumes, with a vee of birds overhead - pelicans again, 23 of them in perfect alignment. I glimpse them just as they begin to glide (after an interval of wingbeats), and not one individual moves a feather. Theirs is a unisoned flight, a huge arrow drifting cloudlike through the sky. I seem lost in time for a few seconds, watching them until, in unison again, their wings start a slow flapping.

Now we are homeward bound, the sun dipping to the horizon, the light soft: a good time for photographs. We are moseying along a different route - municipal roads and trails two miles north of the highway. The Minichinas Hills are all about us, and our journey seems to be as much up and down as westward. There are little ponds among the hills, looking like Scottish Highland tarns. On one of them, Franklin Gulls swim in a tight flock; others fly above the hillshaded water. This will be their refuge for the night after spending the day afield - on some farmer's field, following the tractor, pitching down for beetles and grubs in the overturned soil.

Presently, we are skirting another of the chain of alkali flats encountered before. On a tufted island of grass near shore, a Great Blue Heron stands in silent, classic pose, unmoving, as in a Japanese silkscreen. Is it the same heron we had seen before? Possibly, but while I am getting my camera ready, it departs, once more trailing its precious legs elsewhere.

Next in view is a Great Horned Owl veering off the road ahead of us and sailing low over a grassy meadow. Since our eyes are riveted on it, we do not at first see two young owls directly in front of us, each skittering along opposite sides of the trail. They are near adult size but still whitish - like two scraggy balls making a getaway. I have never seen owls run before, and the sight of these two "ookpiks" ahead of us causes my wife and me to burst out laughing.

I immediately stop the car, and at the same time the young owls take off, for they can fly well. Fly, yes, but land with some difficulty. One bobbles onto a perch at the top of a roadside aspen and glares at us. The second tries for a lower limb, overshooting its mark, yet catching the claws of one foot on the branch. The result: a somersault about the limb, then dangling from it by one leg, head downwards, wings outstretched. It takes a quarter minute before the owl disengages itself and plops to the ground, where it stands erect to observe us. With this spectacle over, we notice a fourth owl, an adult, sitting on a tree stub, ear tufts uplifted slightly. It has been watching the young, and us, the whole time.

The sun has almost set. A warm glow covers the hills and fields, those not already in deep shadow. As we pass a small pothole of water 


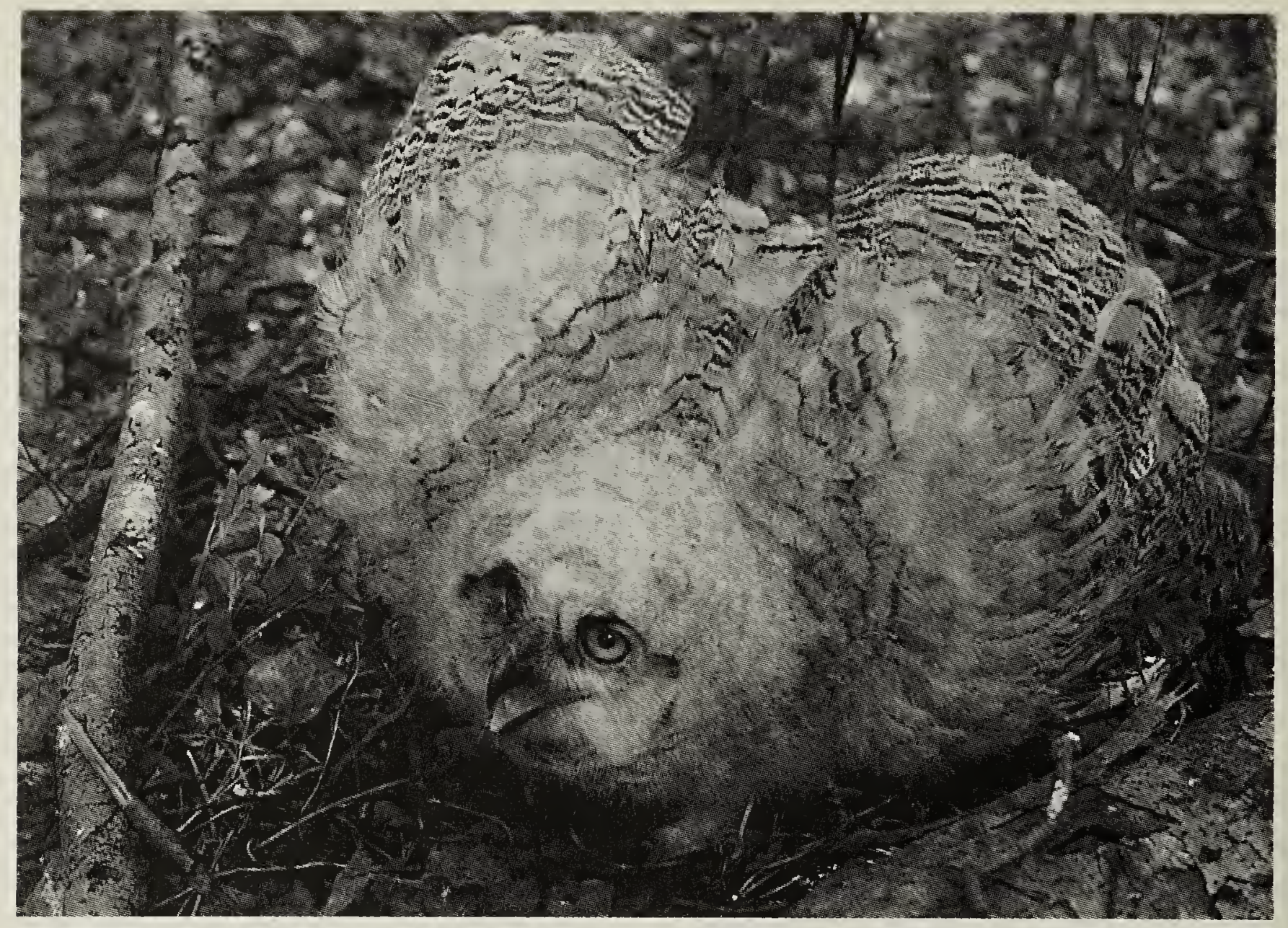

in a field, a heron, most likely the one we disturbed before, heavily takes wing, uttering a hoarse squawk. We will see it no more.

Then at a sharp bend in the road, my eyes are attracted to more "herons" behind us, but a second glance affirms them to be Sandhill Cranes. Cranes in June in the Rosthern area are an uncommon sight, likely a latemigrating flock. There are ten of them standing more or less in a row, turned this way and that. I have been driving very slowly up to now, and just as slowly I turn the car to get a better view; the birds are bathed in a ruddy light, the grasses behind them more gold than green. Then the cranes begin to dance - we hold our breath - and the stately creatures step gingerly about and lift up their wings. We are only 50 yards distant.

Some time later we are travelling westward again in the gathering darkness. Two miles from Rosthern, another (silhouetted) Great Horned Owl hoots from the cross-arm of a power pole, bending forward in a crowing-rooster fashion. It has been a memorable bird drive.

\section{Bird Names}

Costa, Louis Marie Panteleon (1806-1864) Marquis de Beau-Regard and collector of hummingbird specimens - Costa's Hummingbird.

Craveri, Frederico (1815-1890) Italian scientist, chemistry teacher and ardent collector - Craveri' Murrelet. 